\title{
Bilateral asymmetric traumatic hip dislocation with bilateral acetabular fracture: case report
}

\author{
İki taraflı asimetrik travmatik kalça çıkı̆̆ı ve iki taraflı asetabulum kırığı: \\ Olgu sunumu
}

\author{
Ercan OLCAY, ${ }^{1}$ Oktay ADANIR, ${ }^{2}$ Erdem ÖZDEN, ${ }^{1 \text { \# }}$ Alican BARIŞ ${ }^{1 ~}$ ศ
}

Bilateral traumatic hip dislocation is a very rare condition. Simultaneous anterior and posterior traumatic dislocation of both hips is even more unusual. A case report of a bilateral asymmetrical hip joint dislocation with bilateral acetabular fracture in a 28 -year-old man is presented.

Key Words: Acetabular fracture; bilateral traumatic hip dislocation.
İki taraflı travmatik kalça çıkığı nadir görülen bir durumdur. Her iki kalçanın aynı zamanda öne ve arkaya çıkığı daha da nadirdir. Bu yazıda, 28 yaşındaki bir erkek hastada iki taraflı asimetrik kalça çıkığı ile birlikte görülen iki taraf11 asetabulum kırı̆̆ 1 sunuldu.

Anahtar Sözcükler: Asetabulum kırığı; travmatik kalça çıkığı.
Traumatic hip dislocation is a true orthopedic emergency, which generally occurs as a result of highenergy trauma and can cause serious complications. Its frequency has increased with technological advances, and traumatic hip dislocations currently represent $5 \%$ of all dislocations. ${ }^{[1]}$ In a review of the literature to date, we found totally 58 reported cases of bilateral traumatic hip dislocation. ${ }^{[2,3]}$ Only four cases of asymmetric hip dislocations with unilateral acetabular fracture have been reported to date. ${ }^{[3-6]}$ A single case of asymmetric hip dislocation with bilateral acetabular fracture has been reported. ${ }^{[2]}$

In this article, a 28-year-old male with right anterior and left posterior hip dislocations and right acetabular anterior and left acetabular posterior rim fractures is presented.

\section{CASE REPORT}

A 28-year-old male patient was admitted to our emergency department approximately one hour after being involved in a motor vehicle accident. He was previously healthy and had no prior history of pelvic trauma, hip abnormality or ligamentous laxity. On arrival, he was conscious (Glasgow coma score 15), but did not remember the time period in which the accident occurred. His vital signs (arterial blood pressure, peripheral pulse rate and respiratory rate) were normal. The patient complained of severe pain in both hips. On the physical examination, he had a $5 \mathrm{~cm}$ wound at the occipital region and multiple dermal abrasions on his face and extremities. On examination of the extremities, the left limb had an adduction, flexion and internal rotation deformity and the right limb had an abduction, flexion and external rotation deformity. There was no neurovascular deficit. In the radiological evaluation, anterior dislocation of the right hip and anterior rim fracture and posterior dislocation of the left hip and posterior rim fracture were determined. Both anterior and posterior dislocations were evaluated as type 1 according to the Thompson-Epstein classification (Fig. 1). ${ }^{[7,8]}$

Both hips were reduced under general anesthesia approximately 90 minutes after trauma using the Bigelow method, and then stability of the hips was evaluated. Skeletal traction was applied on both distal femurs. The wound at the occipital region was sutured. Before the patient was hospitalized in the ward, postreduction radiographs and computerized tomographic (CT) views were obtained (Fig. 2). Post-reduction views revealed congruent reduction of both hips and

\footnotetext{
${ }^{1}$ Department of Orthopaedics and Traumatology, Kafkas University Faculty of Medicine, Kars; ${ }^{2}$ Department of Orthopaedics and Traumatology
} Bagcllar Training and Research Hospital, Istanbul, Turkey.

${ }^{1}$ Kafkas Üniveritesi Tıp Fakültesi Ortopedi ve Travmatoloji Anabilim Dalı, Kars; ${ }^{2}$ Bağcılar Eğitim ve Araştırma Hastanesi, Ortopedi ve Travmatoloji Kliniği, İstanbul.

Current affiliation: "Baltalimanı Training and Research Hospital, İstanbul; 'İstanbul Training and Research Hospital, İstanbul. 


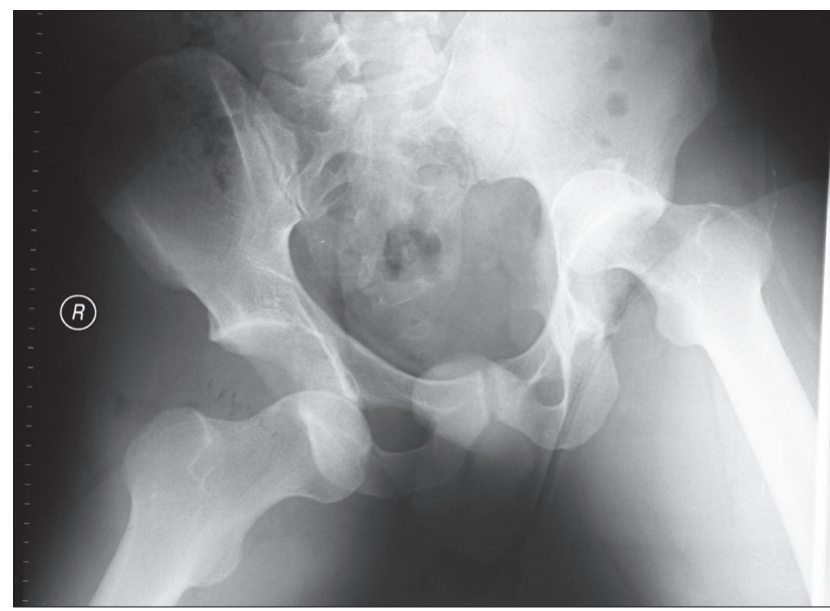

Fig. 1. The initial radiograph.

associated bilateral non-displaced acetabulum fracture. The patient was hospitalized in the ward and consultations were obtained from the general surgery, chest surgery, neurosurgery, and urology departments. Appropriate medication for the prevention of pain, infection, deep vein thrombosis, and heterotopic ossification was started.

On the second day, strengthening exercises for the quadriceps were begun. In the third week, skeletal tractions were removed and the patient was permitted to sit in the bed. In addition, passive exercises for the hip and active and passive exercises for the knees were started. The patient was permitted to walk with complete weight-bearing from the fourth month. He was followed for 32 months, with quarterly visits in the first year and at six-month intervals thereafter. The patient's clinical and radiological findings were evaluated as excellent according to Thompson-Epstein clinical and radiological criteria. At the last visit, no sign of avascular necrosis or osteoarthritis was found on the hip radiograph or magnetic resonance imaging (MRI) (Figs. 3, 4).

\section{DISCUSSION}

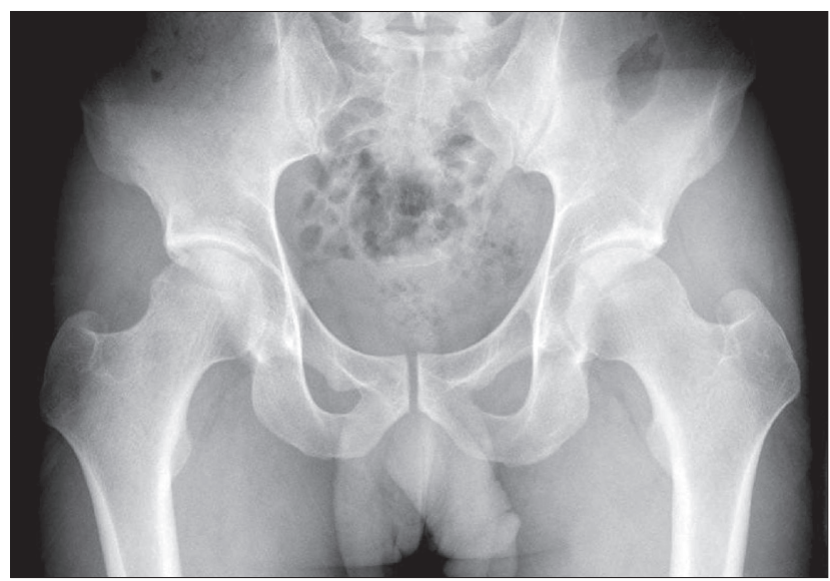

Fig. 3. The follow-up radiograph at the 32 nd month.

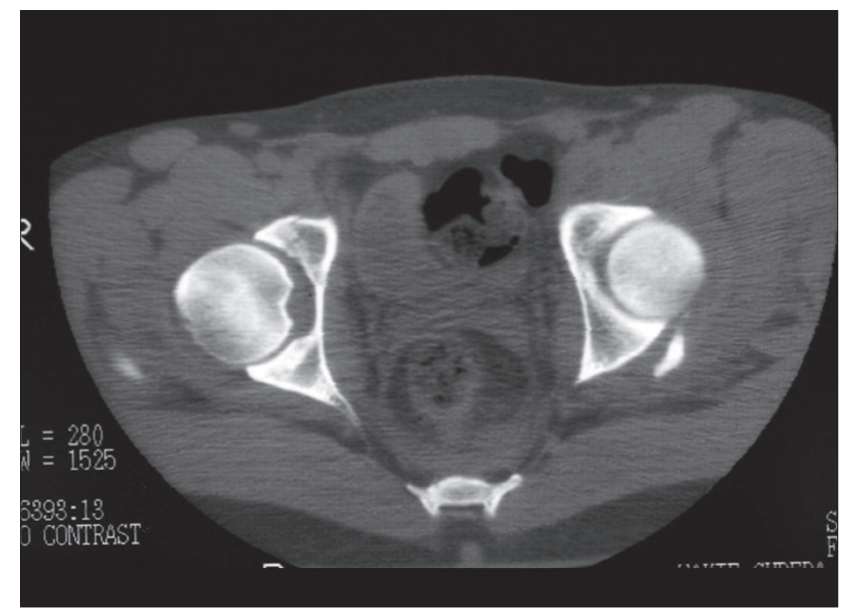

Fig. 2. The post-reduction CT view.

The hip joint is a rather stable articulation with its anatomical structure, strong ligaments and muscles. ${ }^{[9,10]}$ Therefore, dislocations of the hip joint can only be caused by high-energy trauma. Nowadays, frequency of hip dislocation is increasing because of technological advances and the changing lifestyle of the population.

It has been reported that traumatic hip dislocations represent $5 \%$ of all dislocations. ${ }^{[1]}$ In the English literature, there have been a total of 58 cases with bilateral hip dislocation. ${ }^{[2,3]}$ Those are cases with pure dislocation or with accompanying injuries like sciatic nerve injury, femoral fracture, patellar fracture, and acetabulum and femoral head fracture. ${ }^{[11,12]}$ Only four cases with asymmetric hip dislocation and unilateral acetabular fracture have been reported to date. ${ }^{[3-6]}$ Furthermore, a single case with asymmetric hip dislocation and bilateral acetabular fracture has been reported. ${ }^{[2]}$

The hip position during trauma defines the direction of dislocation. According to the opinion generally accepted, if the leg is adducted-flexed and internally rotated, posterior dislocation occurs, whereas if the leg is abducted-flexed and externally rotated, anterior dis-

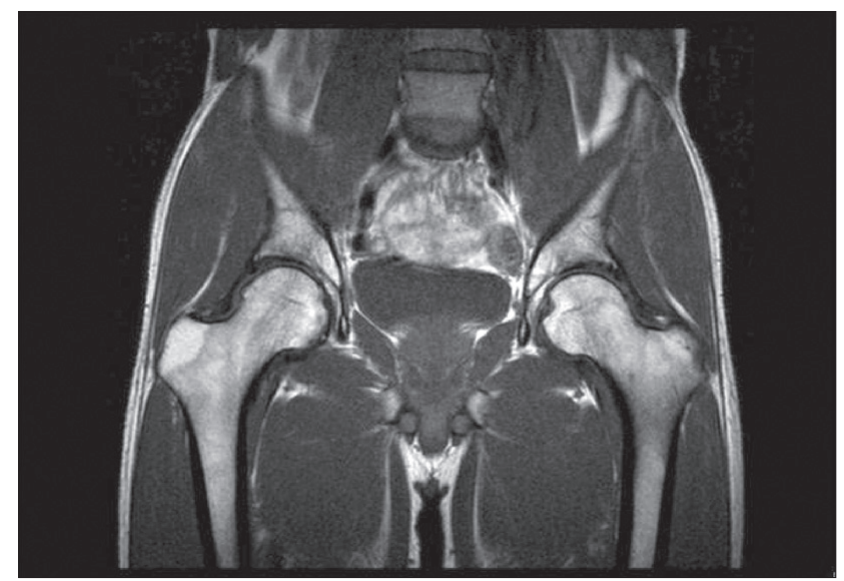

Fig. 4. The follow-up MRI at the 32nd month. 
location occurs. ${ }^{[13-15]}$

For traumatic hip dislocations, the most important prognosing factor is the time period prior to the reduction. ${ }^{[13,16,17]}$ Many authors emphasize that the reduction should be performed within the first six hours. ${ }^{[9,16-}$ ${ }^{18]}$ The rates of avascular necrosis for the cases with early and delayed reduction were reported as $6-27 \%$ and $48 \%$, respectively. ${ }^{[13,16,18]}$ In addition, the force of trauma and recurrent maneuvers for reduction increase the risk of avascular necrosis. ${ }^{[19]}$ It has been reported that the risk of coxarthrosis is proportionally increased with the severity of the trauma. This rate has ranged from $17-48.8 \%$ proportionally related to the follow-up period ${ }^{[9]}$ Another prognosing factor is the direction of dislocation. While the prognosis for central dislocations is the worst, it is best for anterior dislocations. Associated acetabular and femoral head fractures also worsen the prognosis. ${ }^{[9,10,13,17-19]}$ In addition, in hip dislocation, sciatic nerve injury can occur at a rate of $7-19 \% .{ }^{[5,20]}$ Other potential complications are heterotopic ossification, deep venous thrombosis and limitation of hip motion.

In hip dislocation, weight-bearing after reduction is controversial. It has been emphasized that traction is unnecessary if the hip joint is stable on post-reduction examination. ${ }^{[18,19]}$ Though there are publications reporting better results with early mobilization, ${ }^{[10,16]}$ there are also publications that declare that delayed weight-bearing does not alter the prognosis or the risk of avascular necrosis. ${ }^{[17]}$

In the follow-up, quarterly radiological monitoring is necessary in the course of 18 months. ${ }^{[21]}$ Postreduction $\mathrm{CT}$ scan is recommended to determine intra-articular free fragments, reduction and associated femoral head and acetabular fractures; however, the most efficient and harmless method for diagnosis and follow-up of avascular necrosis is MRI. ${ }^{[22]}$

There are no statistical data available in the literature about complication rates of bilateral dislocations because of the insufficient number of the cases, but it is obvious that complications can occur more often with bilateral than unilateral dislocations. Thus, more careful attention should be given to these cases.

In conclusion, traumatic hip dislocation is a true orthopedic emergency. Proper diagnosis, early closed or open reduction, and evaluation of the reduction with CT are important for a good outcome.

\section{REFERENCES}

1. Altay M, Yağmurlu F, Heybeli M, Muratli HH, Tabak Y, Biçimoğlu A. Simultaneous asymmetric bilateral traumatic hip dislocation: a case report. [Article in Turkish] Acta
Orthop Traumatol Turc 2003;37:182-6.

2. Sahin O, Ozturk C, Dereboy F, Karaeminogullari O. Asymmetrical bilateral traumatic hip dislocation in an adult with bilateral acetabular fracture. Arch Orthop Trauma Surg 2007;127:643-6.

3. Pascarella R, Maresca A, Cappuccio M, Reggiani LM, Boriani S. Asymmetrical bilateral traumatic fracture dislocation of the hip: a report of two cases. Chir Organi Mov 2008;92:109-11.

4. Kaleli T, Alyüz N. Bilateral traumatic dislocation of the hip: simultaneously one hip anterior and the other posterior. Arch Orthop Trauma Surg 1998;117:479-80.

5. Shukla PC, Cooke SE, Pollack CV Jr, Kolb JC. Simultaneous asymmetric bilateral traumatic hip dislocation. Ann Emerg Med 1993;22:1768-71.

6. Martínez AA, Gracia F, Rodrigo J. Asymmetrical bilateral traumatic hip dislocation with ipsilateral acetabular fracture. J Orthop Sci 2000;5:307-9.

7. Epstein HC. Traumatic dislocations of the hip. Clin Orthop Relat Res 1973;92:116-42.

8. Thompson VP, Epstein HC. Traumatic dislocation of the hip; a survey of two hundred and four cases covering a period of twenty-one years. J Bone Joint Surg [Am] 1951;33$\mathrm{A}(3): 746-78$.

9. Yang RS, Tsuang YH, Hang YS, Liu TK. Traumatic dislocation of the hip. Clin Orthop Relat Res 1991;(265):218-27.

10. Schlickewei W, Elsässer B, Mullaji AB, Kuner EH. Hip dislocation without fracture: traction or mobilization after reduction? Injury 1993;24:27-31.

11. Maqsood M, Walker AP. Asymmetrical bilateral traumatic hip dislocation with ipsilateral fracture of the femoral shaft. Injury 1996;27:521-2.

12. Toms AD, Williams S, White SH. Obturator dislocation of the hip. J Bone Joint Surg [Br] 2001;83:113-5.

13. Goddard NJ. Classification of traumatic hip dislocation. Clin Orthop Relat Res 2000;(377):11-4.

14. Phillips AM, Konchwalla A. The pathologic features and mechanism of traumatic dislocation of the hip. Clin Orthop Relat Res 2000;(377):7-10.

15. Brooks RA, Ribbans WJ. Diagnosis and imaging studies of traumatic hip dislocations in the adult. Clin Orthop Relat Res 2000;(377):15-23.

16. Dreinhöfer KE, Schwarzkopf SR, Haas NP, Tscherne H. Isolated traumatic dislocation of the hip. Long-term results in 50 patients. J Bone Joint Surg [Br] 1994;76:6-12.

17. Rodríguez-Merchán EC. Osteonecrosis of the femoral head after traumatic hip dislocation in the adult. Clin Orthop Relat Res 2000;(377):68-77.

18. Alonso JE, Volgas DA, Giordano V, Stannard JP. A review of the treatment of hip dislocations associated with acetabular fractures. Clin Orthop Relat Res 2000;(377):32-43.

19. Yang EC, Cornwall R. Initial treatment of traumatic hip dislocations in the adult. Clin Orthop Relat Res 2000;(377):2431.

20. Brav CEA. Traumatic dislocation of the hip. J Bone Joint Surg [Am] 1962;44:1115-1134

21. Dudkiewicz I, Salai M, Horowitz S, Chechik A. Bilateral asymmetric traumatic dislocation of the hip joints. J Trauma 2000;49:336-8.

22. Mitchell MD, Kundel HL, Steinberg ME, Kressel HY, Alavi A, Axel L. Avascular necrosis of the hip: comparison of MR, CT, and scintigraphy. AJR Am J Roentgenol 1986;147:6771. 